\title{
Distribution of Menaquinones in Actinomycetes and Corynebacteria
}

\author{
By M. D. COLLINS, T. PIROUZ AND M. GOODFELLOW \\ Department of Microbiology, The University, Newcastle upon Tyne NEI $7 R U$ \\ AND D. E. MINNIKIN \\ Department of Organic Chemistry, The University, \\ Newcastle upon Tyne NEI $7 R U$
}

(Received 22 December 1976)

\begin{abstract}
S UMMARY
Menaquinones were the only isoprenoid quinones found in 48 corynebacteria and actinomycete strains examined. Dihydromenaquinones having nine isoprene units were the main components isolated from Gordona, Mycobacterium, Corynebacterium bovis, Corynebacterium glutamicum and a strain labelled Nocardia farcinica, but dihydromenaquinones having eight isoprene units were characteristic of other Corynebacterium species and representatives of the 'rhodochrous' complex. Tetrahydromenaquinones having six and eight isoprene units were found in Nocardia strains and in a single strain of Micropolyspora brevicatena, which also contained mycolic acids similar in chain length to those of Nocardia. Menaquinones having nine isoprene units with from one to five double bonds hydrogenated were the main components in Actinomadura madurae, Actinomadura pelletieri, Micropolyspora faeni, Oerskovia turbata and Streptomyces strains. Actinomadura dassonvillei strains had a characteristic pattern of di-, tetra- and hexahydromenaquinones with Io isoprene units which was slightly different from the pattern in mixtures of similar quinones from Actinomyces israelii and Actinomyces viscosus.
\end{abstract}

\section{INTRODUCTION}

The results of lipid analyses have clarified the classification of nocardioform and related bacteria (Lechevalier, 1976; Minnikin \& Goodfellow, 1976). The most productive studies have involved analyses of mycolic acids (Lechevalier, Horan \& Lechevalier, I97I ; Maurice, Vacheron \& Michel, I97I; Azuma et al., I974; Alshamaony, Goodfellow \& Minnikin, 1976a; Alshamaony et al., 1976b) and polar lipids (Khuller \& Brennan, 1972; Pommier \& Michel, 1973; Komura et al., 1975).

Isoprenoid quinones are widely distributed in bacteria (Thomson, 1971) but systematic studies on their occurrence in actinomycetes and related taxa have not been carried out. The most common types of isoprenoid quinones are menaquinones (I) and ubiquinones (II). Menaquinones, 2-methyl-3-polyprenyl-I,4-naphthoquinones (I), show variations in the length and degree of unsaturation of the polyprenyl chain (Thomson, 197I), and in quinones isolated from Streptococcus faecalis (Baum \& Dolin, 1965) and Haemophilus parainfluenzae (Lester, White \& Smith, 1964) the methyl group in the 2-position is absent. Ubiquinones, 2,3-dimethoxy-5-methyl-6-polyprenyl-I,4-benzoquinones (II), also show variations in the polyprenyl chain, and in 'rhodoquinone', isolated from Rhodospirillum rubrum, the methoxyl group in the 3-position is replaced by an amino group (Thomson, 197I). Menaquinones and 
I<smiles>CC=CCC1=C(C)C(=O)c2ccccc2C1=O</smiles>

Menaquinone- $n$

$(\mathrm{MK}-n)$<smiles>CCCCC1=C(C)C(=O)C(OC)=C(OC)C1=O</smiles>

Ubiquinone-n

$(\mathrm{Q}-n)$

ubiquinones are constituents of bacterial plasma membranes (Pennock, I966) and possibly play a role in electron transport and oxidative phosphorylation (Brodie \& Watanabe, 1966; Redfearn, 1966).

The isoprenoid quinone contents of only a few Mycobacterium and Streptomyces strains have been studied (Dunphy, Phillips \& Brodie, I97I; Minnikin \& Goodfellow, I976). In Mycobacterium strains, the predominant menaquinones (I) had nine isoprenoid units with one double bond hydrogenated (dihydromenaquinones), abbreviated as $\mathrm{MK}-\mathrm{g}\left(\mathrm{H}_{2}\right.$ ) (see Biochemical Journal, 1975, 147, 15-2 I for standard nomenclature and abbreviations): but in a streptomycete strain, MK-9 occurred with MK- $9\left(\mathrm{H}_{2}, \mathrm{H}_{4}, \mathrm{H}_{6}\right.$ and $\left.\mathrm{H}_{8}\right), \mathrm{MK}-9\left(\mathrm{H}_{6}\right)$ being the main component. Dihydromenaquinones are also found in corynebacteria; Corynebacterium diphtheriae and $C$. rubrum had $\mathrm{MK}-8\left(\mathrm{H}_{2}\right)$ as the main component (Scholes \& King, I965; Beau, Azerad \& Lederer, 1966$)$ but in C. createnovorans, MK- $9\left(\mathrm{H}_{2}\right)$ predominated (Dunphy et al., I97I).

Actinomycete and related strains representing well defined taxa have been studied to determine the value of isoprenoid quinone markers in their classification.

\section{METHODS}

Cultures. The test strains are listed in Table $\mathrm{I}$. The corynebacteria were maintained on Dorset Egg and Loeffler serum slopes (Cowan, 1974) and the remaining strains on yeast extract agar (Gordon \& Mihm, I962).

Cultivation. The corynebacteria and the Oerskovia strain were grown in shake flasks of nutrient broth (Oxoid) supplemented with I \% (v/v) Tween 80 for 2 to 3 days at $30^{\circ} \mathrm{C}$. The remaining strains were grown in shake culture for 3 to Io days at $30^{\circ} \mathrm{C}$ in modified Sauton's medium (Mordarska, Mordarski \& Goodfellow, 1972); for the rhodochrous strains the latter was supplemented with vitamin $B_{1}\left(50 \mathrm{mg} \mathrm{l}^{-1}\right)$. Cultures were checked for purity at maximum growth, killed by shaking with formalin $(\mathrm{I} \% \mathrm{v} / \mathrm{v})$, separated by centrifuging, washed with distilled water and freeze-dried. The Actinomyces strains were grown in BBL Actinomyces Broth in tightly stoppered I 1 bottles at $37^{\circ} \mathrm{C}$ for 7 to Io days.

Extraction and purification of menaquinones. Dried organisms (100 $\mathrm{mg}$ ) were mixed with $20 \mathrm{ml}$ chloroform/methanol $(2: \mathrm{I}, \mathrm{v} / \mathrm{v})$ and the suspension was stirred continuously overnight. Organisms were then removed by filtration and the extract was evaporated to dryness under reduced pressure at low temperature $\left(<37^{\circ} \mathrm{C}\right)$. Analytical thin-layer chromatography of quinones was performed using $0.5 \mathrm{~mm}$ layers of Merck Kiesel-gel $\mathrm{HF}_{254}$ and a developing solvent consisting of petroleum ether (b.p. 60 to $80^{\circ} \mathrm{C}$ )/diethyl ether $(85: 15, \mathrm{v} / \mathrm{v})$. In this system menaquinones migrate much faster $\left(R_{F} \sim 0.7\right)$ than ubiquinones $\left(R_{F} \sim 0.4\right)$; vitamin $\mathrm{K}_{1}$ (Sigma) and ubiquinone-5o $(\mathrm{BDH})$ were used as chromatographic standards. Menaquinones were routinely detected on thin-layer chromatograms by brief irradiation with short-wave ultraviolet light $(254 \mathrm{~nm})$. Menaquinones were isolated from extracts by 


\section{Table I. Designation and sources of test strains}

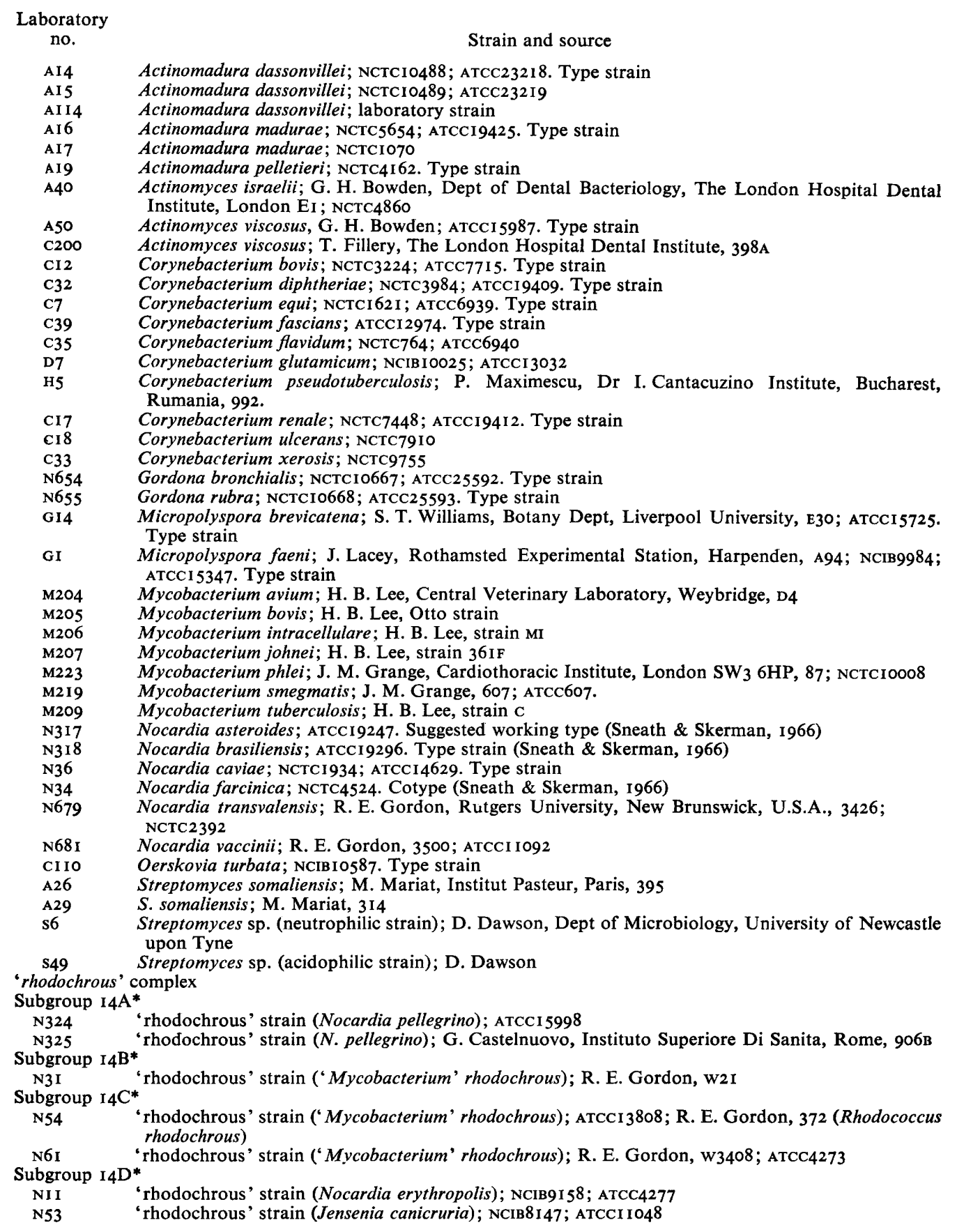

* Phena recovered by Goodfellow (I97I). 
preparative thin-layer chromatography; chloroform was used to elute the quinone from the silica gel.

Analysis of menaquinones. Ultraviolet spectra of menaquinones were recorded in hexane solution. Mass spectra of menaquinones were recorded on an AEI MS9 instrument using a direct insertion probe, an ionizing voltage of $70 \mathrm{eV}$ and a temperature range of 200 to $230^{\circ} \mathrm{C}$.

Analysis of mycolic acids. Whole organisms (100 mg) of the Micropolyspora strains were degraded by acid methanolysis as described previously (Minnikin, Alshamaony \& Goodfellow, 1975). Methyl esters of mycolic acids were detected and purified using the chromatographic system described above. Conditions for the analysis of mycolic esters by mass spectroscopy were the same as for the menaquinone samples.

Partial mass spectra of the menaquinones from all the strains (Table I) have been deposited with the British Lending Library, Boston Spa, Yorkshire LS23 7 BQ, as Supplementary Publication No. SUP 28006 (I 3 pages). Copies may be obtained from the BLL on demand. Where possible, requests should be accompanied by prepaid coupons (held by many university and technical libraries and by the British Council).

\section{RESULTS}

Components that co-chromatographed with vitamin $\mathrm{K}_{1}$ were the only isoprenoid quinones detected by thin-layer chromatography in extracts of the strains studied (Table I). After isolation by preparative thin-layer chromatography, representative samples were examined by ultraviolet spectroscopy and found to have absorption maxima at 242, 248, 260, 270 and $325 \mathrm{~nm}$ in accordance with published data for menaquinones (I) (Dunphy \& Brodie, I97I).

The mass spectra of the menaquinone samples showed, as expected from published data (Azerad \& Cyrot-Pelletier, I973), intense peaks at $m / e$ I 87 and 225 derived from the naphthoquinone nucleus and strong peaks corresponding to molecular ions $\left(\mathbf{M}^{+}\right)$. All mass spectra contained small peaks corresponding to loss of a methyl group from molecular ions $\left(\mathrm{M}^{+}-\mathrm{I} 5\right)$ and occasionally peaks of low intensity were seen at $\mathrm{M}^{+}+\mathrm{I} 6$. The latter may be due to partial oxidation of the sample during its preparation for mass spectrometry; epoxides have been detected as minor components, possibly artefacts, in ubiquinone samples (Friis, Daves \& Folkers, 1967). These minor peaks do not, however, interfere with the analysis of menaquinones by mass spectrometry provided they are not mistaken for molecular ions. The results of the mass spectral analyses of the menaquinones isolated from the test strains are shown in Tables 2 to 5 .

The predominant menaquinone found in the majority of the Corynebacterium strains and representatives of the 'rhodochrous' complex (Goodfellow, I97I) was MK- $8\left(\mathrm{H}_{2}\right)$ (Table 2). However, Corynebacterium bovis and C. glutamicum strains had $\mathrm{MK}-9\left(\mathrm{H}_{2}\right)$ as the main menaquinone component, as did representatives of Gordona, Mycobacterium and Nocardia farcinica $\mathrm{N} 34$ (Table 3).

The mass spectra of the menaquinones from other Nocardia strains and Micropolyspora brevicatena GI4 (Table 4 ) contained predominant peaks at $m / e 720$ corresponding to tetrahydromenaquinones MK- $8\left(\mathrm{H}_{4}\right)$. Small peaks were found for MK-7 components at $m / e 652$ but larger peaks attributable to $\mathrm{MK}-6\left(\mathrm{H}_{4}\right)$ were seen at $m / e$ 584. Small unexplained peaks were observed at $m / e 596$, I2 mass units higher than the major peaks at $m / e 584$. Thin-layer chromatographic analysis of a whole-organism methanolysate of Micro. brevicatena GI4 revealed a component migrating in a similar manner to methyl esters of mycolic acids isolated from Nocardia (Minnikin et al., 1975). Mass spectroscopic analysis of this component gave a series of peaks from $m / e 682$ to 814 attributable to anhydromycolic esters 
Table 2. Peaks corresponding to molecular ions in the mass spectra of menaquinones isolated from strains of Corynebacterium and the 'rhodochrous' complex

The main component of each series is denoted by +++ , any components greater than $50 \%$ of the main peak by ++ , and all other significant components by + .

Menaquinone isoprenologue

Degree of hydrogenation $m / e$

C. equi $\mathrm{C} 7$

C. flavidum $\mathrm{C} 35$

C. diphtheriae $\mathbf{C 3 2}$

C. fascians $\mathbf{C 3 9}$

C. pseudotuberculosis $\mathrm{H} 5$

C. renale $\mathrm{CI} 7$

C. ulcerans $\mathrm{CI} 8$

C. xerosis $\mathrm{C} 33$

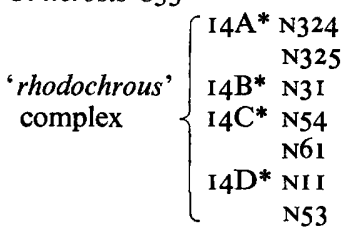

$\mathrm{MK}-7$
$\left(\mathrm{H}_{2}\right)$
650
+
+
+
+
+
+
+
+
+
+
+
+
+
+

MK-8

$\begin{array}{cccc}\overbrace{-1} & \left(\mathrm{H}_{2}\right) & \left(\mathrm{H}_{4}\right) & \left(\mathrm{H}_{2}\right) \\ +6 & 718 & 720 & 786 \\ + & +++ & + & + \\ - & +++ & ++ & + \\ + & +++ & - & - \\ + & +++ & - & - \\ + & +++ & - & - \\ + & +++ & - & - \\ + & +++ & - & - \\ + & +++ & - & - \\ + & +++ & - & - \\ + & +++ & - & - \\ + & +++ & - & - \\ + & +++ & + & - \\ + & +++ & - & - \\ + & +++ & - & -\end{array}$

* Subgroups of the 'rhodochrous' complex (Goodfellow, I97I).

Table 3. Peaks corresponding to molecular ions in the mass spectra of menaquinones isolated from strains of Corynebacterium, Gordona, Mycobacterium and Nocardia farcinica

The main component in each series is denoted by +++ , any components greater than $50 \%$ of the main peak by ++ , and all other significant components by + .

Menaquinone isoprenologue

Degree of hydrogenation $m / e$

C. bovis $\mathrm{Cr} 2$

C. glutamicum $\mathrm{D} 7$

G. bronchialis N654

G. rubra $\mathrm{N} 655$

Myco. avium M204

Myco. bovis M205

Myco. intracellulare M206

Myco. phlei M223

Myco. johnei м207

Myco. smegmatis M219

Myco. tuberculosis M209

N. farcinica N34
MK-8

$\begin{array}{ccc}- & \left(\mathrm{H}_{2}\right) & \left(\mathrm{H}_{4}\right) \\ 7 \mathrm{I} 6 & 7 \mathrm{I} 8 & 720 \\ + & + & - \\ - & + & - \\ - & + & - \\ - & + & - \\ - & + & - \\ + & + & - \\ - & + & - \\ - & + & + \\ - & + & - \\ - & + & - \\ - & + & - \\ - & + & +\end{array}$

MK-9

MK-IO

\begin{tabular}{cccc}
\hline & $\left(\mathbf{H}_{2}\right)$ & $\left(\mathbf{H}_{4}\right)$ & $\left(\mathbf{H}_{2}\right)$ \\
784 & 786 & 788 & 854 \\
+ & +++ & - & + \\
+ & +++ & - & - \\
+ & +++ & - & - \\
+ & +++ & - & - \\
+ & +++ & + & - \\
+ & +++ & - & - \\
+ & +++ & - & - \\
+ & +++ & + & - \\
+ & +++ & - & - \\
+ & +++ & - & - \\
+ & +++ & - & - \\
+ & +++ & + & -
\end{tabular}

corresponding to mycolic acids having from 46 to 56 carbon atoms (Alshamaony et al., I976a). In contrast, the Micro. faeni strain did not contain mycolic acids.

A variety of menaquinone patterns were found in actinomycete strains which lack mycolic acids (Table 5). The streptomycetes had MK-9 $\left(\mathrm{H}_{6}\right)$ as the main component but MK- $9\left(\mathrm{H}_{4}\right)$ and $\mathrm{MK}-9\left(\mathrm{H}_{8}\right)$ occurred in comparable proportions. Related menaquinone patterns (Table 5) were found for representatives of Micro. faeni, Actinomadura madurae and Actinomadura pelletieri but the proportions of MK-9 components were different. In Actinomyces 
Table 4. Peaks corresponding to molecular ions in the mass spectra of menaquinones isolated from strains of Nocardia and Micropolyspora brevicatena

The main component in each series is denoted by +++ , any components greater than $50 \%$ of the main peak by ++ , and all other significant components by + .

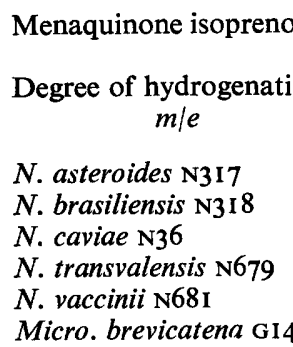

$\begin{array}{cc}\text { MK-6 } & \text { MK-7 } \\ \left(\mathbf{H}_{4}\right) & \left(\mathbf{H}_{4}\right) \\ 584 & 652 \\ ++ & + \\ ++ & + \\ ++ & + \\ ++ & + \\ ++ & - \\ + & +\end{array}$

\begin{tabular}{ccc}
\multicolumn{3}{c}{ MK-8 } \\
$\overbrace{\left(\mathrm{H}_{2}\right)}^{\left(\mathrm{H}_{4}\right)}$ & $\left(\mathrm{H}_{6}\right)$ \\
$7 \mathrm{I} 8$ & 720 & 722 \\
+ & +++ & - \\
+ & +++ & - \\
+ & +++ & - \\
+ & +++ & - \\
+ & +++ & + \\
+ & +++ & -
\end{tabular}

israelii and Actinomyces viscosus strains, $\mathrm{MK}-\mathrm{IO}\left(\mathrm{H}_{4}\right)$ predominated but in representatives of Actinomadura dassonvillei comparable amounts of $\mathrm{MK}-\mathrm{Io}\left(\mathrm{H}_{2}\right)$ and $\mathrm{MK}-\mathrm{IO}\left(\mathrm{H}_{6}\right)$ were also present. Oerskovia turbata cI Io had MK- $9\left(\mathrm{H}_{4}\right)$ as the major component.

\section{DISCUSSION}

Numerical phenetic surveys indicate that Actinomadura, Actinomyces, Corynebacterium sensu stricto (Goodfellow, Collins \& Minnikin, 1976), Mycobacterium, Nocardia sensu stricto (Cross \& Goodfellow, I973), Oerskovia and the 'rhodochrous' complex form distinct taxa of equivalent rank (Goodfellow, I97I ; Holmberg \& Nord, I975; Bousfield \& Goodfellow, 1976). Since the distribution of character frequencies is strongly $U$-shaped for homogeneous groups (Sneath, 1976), chemical markers can be expected to be of value in classification of these taxa. The present preliminary studies suggest that menaquinone analyses can provide good characters for the classification of actinomycete and related taxa.

The menaquinones of organisms with a wall chemotype IV (Lechavalier, 1976) which also contain mycolic acids fell into three distinct patterns (Tables 2, 3 and 4). In particular, menaquinone analyses distinguished Nocardia sensu stricto and Micro. brevicatena which contained a mixture of tetrahydromenaquinones with six and eight isoprene units from Corynebacterium, Gordona, Mycobacterium and the 'rhodochrous' complex. Further evidence for a close relationship between Nocardia and Micro. brevicatena was indicated by the mycolic acids of the latter which were similar ( 46 to 56 carbon atoms) to those found in Nocardia sensu stricto (Alshamaony et al., 1976a; Minnikin \& Goodfellow, 1976). In contrast, Micro. faeni GI did not contain mycolic acids and had a menaquinone composition similar to streptomycetes and some actinomadurae. These chemical data therefore suggest that the genus Micropolyspora is heterogeneous and is in need of further study.

The recovery of dihydromenaquinones with nine isoprene units from mycobacteria was consistent with earlier reports (Dunphy et al., 197I) and the presence of similar menaquinones in Nocardia farcinica N34 was not unexpected as it has other mycobacterial properties (Lechevalier, 1976). Magnusson (1976) has proposed that $N$. farcinica N34, and similar strains, be reclassified as Mycobacterium farcinogenes var. senegalense Chamoiseau 1973 . Our data cast doubt on the classification of a strain labelled Mycobacterium flavum which was reported to contain a ubiquinone (Erickson, 197I). 


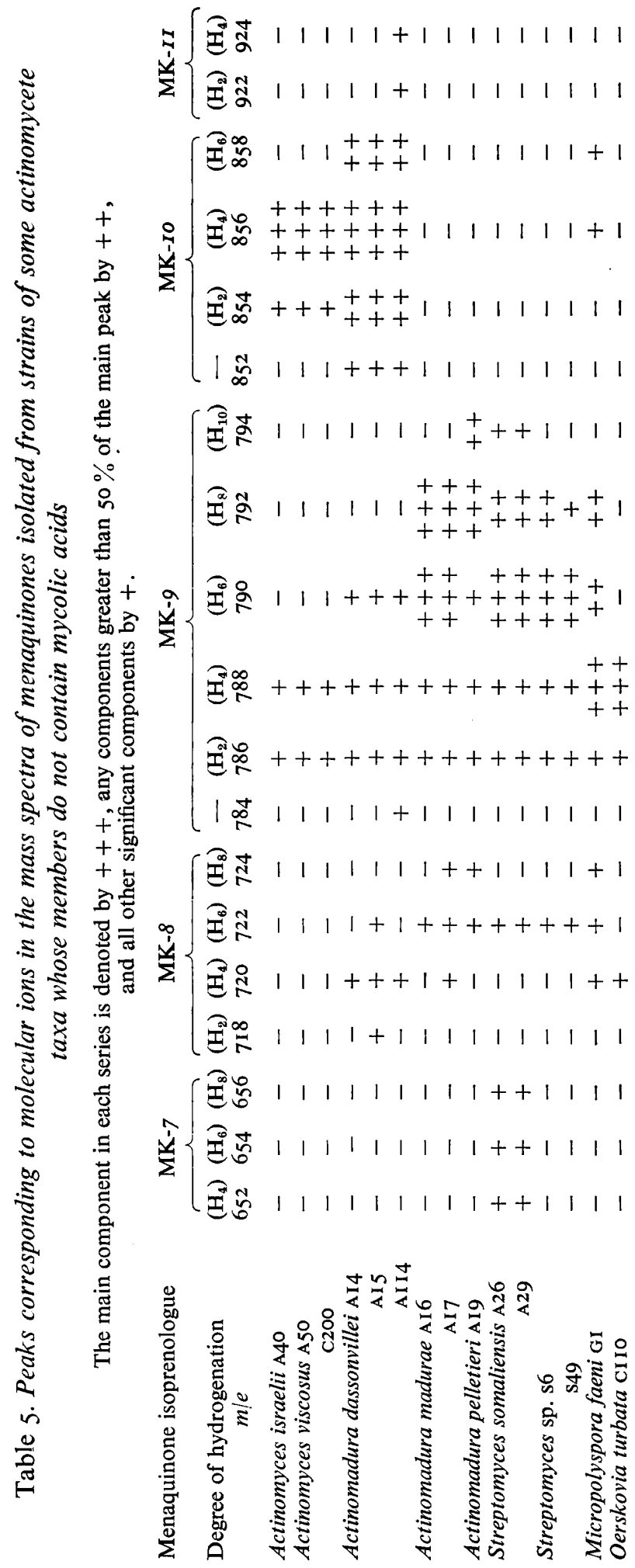


Menaquinone composition also distinguished the animal corynebacteria and representatives of the 'rhodochrous' complex (Goodfellow, 1971), which contained a dihydromenaquinone with eight isoprene units, from mycobacteria and gordonae. Corynebacterium fascians C39 should not be classified with the corynebacteria but in the 'rhodochrous' complex (Goodfellow et al., 1976). The significance of the occurrence of major amounts of MK-g( $\left.\mathrm{H}_{2}\right)$ in $C$. bovis and $C$. glutamicum must await comparative studies on more strains though a similar result has been recorded for a strain labelled Corynebacterium creatovorans (Dunphy et al., I97I). It may also be of interest that a strain labelled Brevibacterium thiogenitalis (Okazaki, Kanzaki \& Fukuda, I968), which contained mycolic acid and produced glutamic acid, had MK- $9\left(\mathrm{H}_{2}\right)$ as the major menaquinone component (Kanzaki et al., 1974).

The relationship between the 'rhodochrous' complex and the genus Gordona is a complex one (Bousfield \& Goodfellow, 1976; Tsukamura, 1975) and it has recently been proposed that they be merged to form the resurrected genus Rhodococcus containing ro species (Goodfellow \& Alderson, I977). Our preliminary findings suggest that menaquinone analyses will provide good characters for the classification of rhodococci.

The menaquinone composition of streptomycetes is in accord with previous studies (Dunphy et al., 197I) and closely related patterns of MK-9 components were also found in Actinomadura madurae, Actinomadura pelletieri and Micro. faeni strains. The different pattern of partially hydrogenated MK-Io components found in Actinomadura dassonvillei strains supports the previous distinction of this species from the other two Actinomadura taxa on the basis of spore morphology (Williams et al., 1976), and content of madurose (Lechevalier \& Gerber, 1970), fatty acid (Agre, Efimova \& Guzeva, 1975) and pigment (Lechevalier, Lechevalier \& Gerber, 1971). Actinomyces israelii and Actinomyces viscosus had a distinct pattern with $\mathrm{MK}-\mathrm{IO}\left(\mathrm{H}_{4}\right)$ as the predominant component.

Cross \& Goodfellow (1973) did not allocate Oerskovia to a family. In a subsequent numerical taxonomic study, Jones (I975) found that the genus Oerskovia shared a higher affinity with coryneform bacteria than with actinomycetes. It was, therefore, interesting that Oerskovia turbata CI Io had MK- $9\left(\mathrm{H}_{4}\right)$ as the major component, a quinone previously found to be characteristic of the genus Propionibacterium (Schwartz, I973; Sone, 1974).

These preliminary analyses suggest that isoprenoid quinones may prove to be of value in the classification of actinomycetes and corynebacteria. However, a greater number of strains need to be studied and the present results, based entirely on mass and ultraviolet spectroscopy, should be substantiated by further detailed studies.

The authors are indebted to Drs G. H. Bowden and J. M. Hardie for the gift of freezedried Actinomyces; to Mr H. B. Lee, Central Veterinary Laboratory, Weybridge, for freezedried mycobacteria; to colleagues who kindly provided cultures (Table I); to Ms G. Alderson and Mr A. Temple for maintaining cultures and preparing cells and to P. Kelly for mass spectroscopy. M.D.C. gratefully acknowledges receipt of a Luccock Scholarship (Medical Scholarships and Research Committee, Faculty of Medicine, Newcastle upon Tyne), and M.G. and D.E.M. wish to thank the Medical Research Council for support (grant G974/522/S). 


\section{REFERENCES}

Agre, N. S., Efimova, T. P. \& Guzeva, L. N. (I975). Heterogeneity of the genus Actinomadura Lechevalier and Lechevalier. Mikrobiologiya 44, 252-257.

Alshamaony, L., Goodfellow, M. \& Minnikin, D. E. (1976a). Free mycolic acids as criteria in the classification of Nocardia and the 'rhodochrous' complex. Journal of General Microbiology 92, I 88-199.

Alshamaony, L., Goodfellow, M., Minnikin, D. E. \& Mordarska, H. (1976 b). Free mycolic acids as criteria in the classification of Gordona and the 'rhodochrous' complex. Journal of General Microbiology 92, I 83-187.

Azerad, R. \& CYrot-Pelletier, M. O. (1973). Structure and configuration of the polyprenoid side chain of dihydromenaquinones from myco- and corynebacteria. Biochimie 55, 591-603.

Azuma, I., Ohuchida, A., Taniyama, T., Yamamura, Y., Shoji, K., Hori, M., Tanaka, Y. \& Ribi, E. (1974). The mycolic acids of Mycobacterium rhodochrous and Nocardia corallina. Biken's Journal r7, I-I 9 .

Baum, R. H. \& Dolin, M. I. (I965). Isolation of 2-solanesyl-I,4-naphthoquinone from Streptococcus faecalis, $10 \mathrm{Cl}$. Journal of Biological Chemistry 240, 3425-3433.

Beau, S., Azerad, R. \& Lederer, E. (1966). Isolément et caractérisation des dihydromenaquinones des myco- et corynébactéries. Bulletin de la Société de chimie biologique 48, 569-581.

Bousfield, I. J. \& Goodfellow, M. (1976). The 'rhodochrous' complex and its relationships with allied taxa. In The Biology of the Nocardiae, pp. 39-65. Edited by M. Goodfellow, G. H. Brownell and J. A. Serrano. London: Academic Press.

Brodie, A. F. \& Watanabe, T. (1966). Mode of action of vitamin $\mathrm{K}$ in micro-organisms. Vitamins and Hormones 24, 447-463.

Chamoiseau, G. (I973). Mycobacterium farcinogenes, agent causal du farcin du boeuf en Afrique. Annales de Micribiologie 124A, 2 15-222.

Cowan, S. T. (1974). Manual for the Identification of Medical Bacteria, 2nd edn. Cambridge: Cambridge University Press.

Cross, T. \& Goodfellow, M. (1973). Taxonomy and classification of the actinomycetes. In Actinomycetales: Characteristics and Practical Importance, pp. I I-I 12. Edited by G. Sykes and F. A. Skinner. London: Academic Press.

DunPhy, P. J. \& Brodie, A. F. (197I). The structure and function of quinones in respiratory metabolism. Methods in Enzymology XVIII, 407-46I.

Dunphy, P. J., Phillips, P. G. \& Brodie, A. F. (197I). Separation and identification of menaquinones from microorganisms. Journal of Lipid Research 12, 442-449.

ERICKSON, S. K. (197I). The respiratory system of the aerobic, nitrogen-fixing, Gram-positive bacterium, Mycobacterium flavum 301. Biochimica et biophysica acta 245, 63-69.

Fris, P., Daves, G. D. \& Folkers, K. (r967). New epoxyubiquinones. Biochemistry 6, 3618-3624.

Groodfellow, M. (I97I). Numerical taxonomy of some nocardioform bacteria. Journal of General Microbiology 69, 33-80.

Groodfellow, M. \& Alderson, G. (1977). The actinomycete-genus Rhodococcus: a home for the 'rhodochrous' complex. Journal of General Microbiology 100, 99-1 22.

Goodfellow, M., Collins, M. D. \& Minnikin, D. E. (1976). Thin-layer chromatographic analysis of mycolic acid and other long-chain components in whole-organism methanolysates of coryneform and related taxa. Journal of General Microbiology 96, 35 I-358.

Gordon, R. E. \& Miнm, J. H. (1962). Identification of Nocardia caviae (Erikson) nov. comb. Annals of the New York Academy of Sciences 98, 628-636.

Holmberg, K. \& NorD, C.-E. (I975). Numerical taxonomy and laboratory identification of Actinomyces and Arachnia and some related bacteria. Journal of General Microbiology 9r, 17-44.

JONES, D. (1975). A numerical taxonomic study of coryneform and related bacteria. Journal of General Microbiology 87, 52-96.

KanZaki, T., Sugiyama, Y., Kitano, K., Ashida, Y. \& Imada, I. (1974). Quinones of Brevibacterium. Biochemica et biophysica acta 348, I62-165.

Khuller, G. K. \& Brennan, P. J. (1972). The polar lipids of some species of Nocardia. Journal of General Microbiology 73, 409-412.

Komura, I., Yamada, K., Otsuka, S. \& Komagata, K. (1975). Taxonomic significance of phospholipids in coryneform and nocardioform bacteria. Journal of General and Applied Microbiology 21, 25I-26r .

LeChevalieR, M. P. (1976). The taxonomy of the genus Nocardia: scme light at the end of the tunnel. In The Biology of the Nocardiae, pp. I-38. Edited by M. Goodfellow, G. H. Brownell and J. A. Serrano. London: Academic Press.

Lechevalier, M. P. \& Gerber, N. N. (1970). The identity of madurose with 3-O-methyl-D-galactose. Carbohydrate Research $\mathrm{I3}_{3}, 45 \mathrm{I}-454$.

Lechevalier, M. P., Horan, A. C. \& Lechevalier, H. A. (1971). Lipid composition in the classification of nocardiae and mycobacteria. Journal of Bacteriology 105, 313-3I 8. 
LeChevalier, H. A., Lechevalier, M. P. \& Gerber, N. N. (I97I). Chemical composition as a criterion in the classification of actinomycetes. Advances in Applied Microbiology 14, 47-72.

LESTER, R. L., WhiTE, D. C. \& SMITH, S. L. (1964). The 2-desmethyl vitamin $\mathrm{K}_{2}$ 's. A new group of naphthoquinones isolated from Haemophilus parainfluenzae. Biochemistry 3, 949-954.

Magnusson, M. (1976). Sensitin tests as an aid in the taxonomy of Nocardia and its pathogenicity. In The Biology of the Nocardiae, pp. 236-265. Edited by M. Goodfellow, G. H. Brownell and J. A. Serrano. London: Academic Press.

MaUrice, M. T., VACHERON, M. T. \& Michel, G. (1971). Isolément d'acides nocardiques de plusieurs espèces de Nocardia. Chemistry and Physics of Lipids 7, 9-18.

MinNIKIN, D. E. \& Goodfellow, M. (1976). Lipid composition in the classification and identification of nocardiae and related taxa. In The Biology of the Nocardiae, pp. I60-219. Edited by M. Goodfellow, G. H. Brownell and J. A. Serrano. London: Academic Press.

Minnikin, D. E., Alshamaony, L. \& Goodfellow, M. (1975). Differentiation of Mycobacterium, Nocardia and related taxa by thin-layer chromatographic analysis of whole-organism methanolysates. Journal of General Microbiology 88, 200-204.

MordarsKa, H., MoRdarsKi, M. \& Goodfellow, M. (1972). Chemotaxonomic characters and classification of some nocardioform bacteria. Journal of General Microbiology $7 \mathbf{1}, 77-86$.

OKAZAKI, H., KANZAKI, T. \& FUKUDA, H. (I968). L-Glutamic acid fermentation. Part V. Behaviour of oleic acid in an oleic acid-requiring mutant. Agriculture and Biological Chemistry 32, r464-1470.

PeNNOCK, J. F. (1966). Occurrence of vitamins $\mathrm{K}$ and related quinones. Vitamins and Hormones 24, 307-329.

Pommier, M. T. \& Michel, G. (1973). Phospholipid and acid composition of Nocardia and nccardoid bacteria as criteria of classification. Biochemical Systematics $\mathbf{1}, 3-\mathrm{I} 2$.

REDFEARN, E. R. (I966). Mode of action of ubiquinones (coenzymes Q) in electron transport systems. Vitamins and Hormones 24, 465-488.

Scholes, P. B. \& KING, H. K. (I965). Isolation of a naphthaquinone with partly hydrogenated side chain from Corynebacterium diphtheriae. Biochemical Journal 97, 766-768.

SchwartZ, A. C. (1973). Terpenoid quinones of the anaerobic Propionibacterium shermanii. Archiv für Mikrobiologie 91, 273-279.

SNEATH, P. H. A. (I976). An evaluation of numerical taxonomic techniques in the taxonomy of Nocardia and allied taxa. In The Biology of the Nocardiae, pp. 74-101. Edited by M. Goodfellow, G. H. Brownell and J. A. Serrano. London: Academic Press.

SNeATh, P. H. A. \& Skerman, V. B. D. (I966). A list of type and reference strains of bacteria. International Journal of Systematic Bacteriology 16, I-133.

SONE, N. (1974). Isolation of a novel menaquinone with a partly hydrogenated side chain from Propionibacterium arabinosum. Journal of Biochemistry 76, 133-136.

Thомson, R. H. (1971). Naturally occurring quinones. London: Academic Press.

TsuKAMURA, M. (1975). Numerical analysis of the relationship between Mycobacterium, rhodochrous group and Nocardia by use of hypothetical median organisms. International Journal of Systematic Bacteriology 25, 329-335.

Williams, S. T., Sharples, G. P., Serrano, J. A., Serrano, A. A. \& Lacey, J. (1976). The micromorphology and fine structure of nocardioform organisms. In The Biology of the Nocardiae, pp. r02-140. Edited by M. Goodfellow, G. H. Brownell and J. A. Serrano. London: Academic Press. 